\title{
Ein Kinderwunsch
}

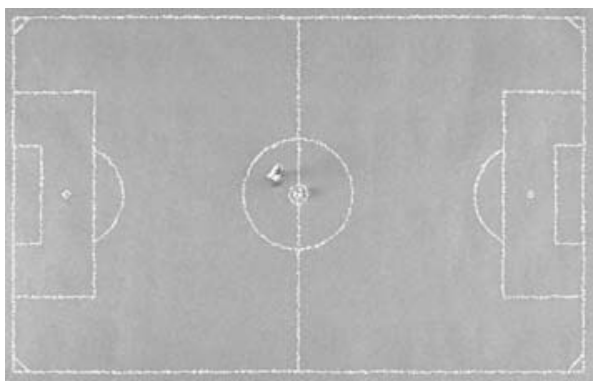

Wenn ich auch einen Vater hätte,

der würde mich zum grossen Fussballplatz fahren.

In der Nacht gab es ein riesiges Feuer und einen betäubenden Knall.

Die Mutti sagte am nächsten Tag rührend:

«Der liebe Gott gibt ein grosses Fest,

und der Vater, meine kleine Schwester,

wie der Mann meiner älteren Schwester

sind bei ihm zu Gast.

Gott liebe die Märtyrer sehr.»

Wenn ich auch einen Vater hätte,

der würde mich auch zum grossen Fussballplatz fahren.

K. Mohtadi, Zofingen

\section{Wundspur}

Vielleicht steht irgendwo geschrieben:

Ich mag das Fleisch nicht,

das gebrannte Fleisch nicht.

Ich habe stets den Geruch verbrannten Fleisches in der Nase, den Geschmack des verbrannten Fleisches in den Stimmbändern. Bomben zerfetzten die Uniform und den Körper der Soldaten; seither habe ich stets den Geruch verbrannten Fleisches in der Nase, den Geschmack verbrannten Fleisches in den Stimmbändern und mag das Fleisch nicht, das gebrannte Fleisch nicht.

K. Mohtadi, Zofingen

\section{Degustieren}

Ich degustiere Tag für Tag von neuem meine Wünsche: dem schwerschnaufenden Strom Geruhsamkeit, der durstigen Wüste erfrischenden Regen, den sehnsüchtigen Fischen Lungen und Füsse, den Menschen Flügeln und Kiemen, den Tauben funktionstüchtiges Gehör, den Stummen sprachfähige Zunge, den Amputierten neue Extremitäten, den Blinden schöne Augen, den Augen ein liebefähiges Herz und dem Herzen Überwindung des Verlangens, dem Verlangen Bescheidenheit und der Bescheidenheit Aufrichtigkeit, der Aufrichtigkeit den edelsten Freisinn, damit Adam mit deren Frucht Eva verführt. Man darf im stillen die eigenen Wünsche degustieren.

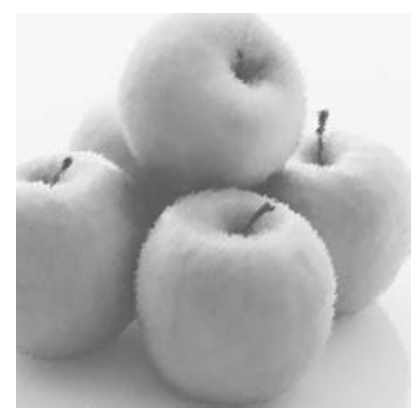

